\title{
ANALYSIS OF CONTEMPORARY MEAT AND MEAT PRODUCTS' PROCESSING METHODS
}

\author{
Rodionova K. O. ${ }^{1}$, Paliy A. P. ${ }^{2}$ \\ ${ }^{1}$ Luhansk National Agrarian University, Ukraine, \\ Kharkiv, e-mail: katerina.rodionova@ukr.net \\ ${ }^{2}$ National Scientific Center 'Institute of Experimental and Clinical \\ Veterinary Medicine', Kharkiv, Ukraine, e-mail: paliy.dok@gmail.com
}

\begin{abstract}
Summary. For today, the issue of maximum preservation of meat and meat products at all stages of their production, storage, transportation and realization does not lose its relevance. Existing ways of food products' preservation for prevention of their microbiological damage are divided into three groups: physical, chemical and biological. The article gives an analysis of modern methods of meat and meat products' processing. Physical (chill, freezing, super freezing, ionizing irradiation, ultraviolet irradiation, pressure processing, laser irradiation) and chemical (with the use of organic acids, trisodium phosphate, extracts of plants with bacteriostatic properties etc.) methods of meat and meat products' preservation are characterized. The data on the methods for extension of realization term due to the use of modern packaging materials (modified atmosphere, system of 'active packaging' and aseptic packaging) is given. The advantages and disadvantages of each of these methods are indicated.
\end{abstract}

Keywords: meat, meat products, method, processing, canning, analysis

Introduction. Meat and meat products remain one of the most consumed products on the world market. From the chemical point of view, the lean muscle tissue of farm animals and poultry consists of water (71-76\%), proteins (20-22\%), fats (lipids, 3-8\%), carbohydrates $(1.2 \%)$, soluble non-protein organic and inorganic substances $(2.3 \%)$ as well as vitamins. From a microbiological point of view, these compounds are nutrients for microorganisms' living activity. That is why the terms of their storage, especially chilled meat and offal, are only 2-4 days. Only a few days are enough for starting of microorganism growth and reproduction under the influence of oxygen, light and temperature.

For today, physical and chemical methods of meat and meat products' preservation, as well as various methods for the extension of realization period using modern packaging materials (modified atmosphere, 'active packages' and aseptic packaging systems) are exist. However, the search of novel and safe method that would ensure the effective and reliable long-time storage of the product (together with keeping of product's quality and safety) is still an essential issue for veterinary and sanitary experts, controllers of ready-to-use products, technologists and commodity researchers.

The aim of this work is to analyze modern meat and meat products' processing methods in order to extend the realization term and to determine their advantages and disadvantages.

Material and methods. The analysis was carried out in the Department of Infectology, Quality and Safety of AIC Production of the Luhansk National Agrarian University. The objects of the research were processing methods of meat and meat products in order to extend the term of their realization.
Results. At the current stage of the meat processing industry development, the entire row of methods which are used for the extension of the term of realization of ready-to-use products, includes the following groups:

\section{Physical methods:}

1. Chill and freezing. Processing of meat and meat products with frost is commonly used and it is one of the best preserving methods. The widespread use of cold is associated with the following positive characteristics:

- ability for rapid preservation of a large quantity of raw materials;

- prolonged storage of meat with maintenance of its properties and nutritional value;

- minimal loss of product's weight during storage;

- the universal use of freezing technology for all kinds of meat raw materials and ready-to-use products;

- lower energy consumption of refrigeration in comparison with other preservation methods;

- possibility to use the frost not only as the main preserving factor, but also in combination with other preserving methods (salt, production of sausages etc.).

However, it is necessary to take into account the disadvantages of this method. First of all, microorganisms are resistant to low temperatures and the majority of bacteria remain viable after freezing. Moreover, some species are even capable for reproduction. Bacterial toxins are not destroyed even after slow or several repeated freezing acts. In addition, the action of low temperatures does not destroy the micellar fungi and yeast, but only reduces their activity (Nastasijevic, Lakicevic and Petrovic, 2018).

2. Super freezing is a refrigeration process that provides a reduction of meat temperature below the 
cryoscopic temperature by $1-2{ }^{\circ} \mathrm{C}$ with partial ice formation (Mok et al., 2017).

The main parameter, which defines the quality of product's super freezing, is the degree of water transition into ice. Generally, the ice content from 5 to $30 \%$ in the product does not lead to a noticeable decrease in product's quality, but might increase the shelf life. The amount of ice in the product over $30 \%$ leads to a large loss of liquid (Stonehouse and Evans, 2015; Wu et al., 2014).

Storage of food products at super freezing temperature has three main advantages:

1) saving of product's freshness;

2) guarantee of product's high quality;

3) inhibition of microorganism's growth.

In addition, it can reduce the impact of freezing/defrosting, and thus increase output, decrease energy, labor and transportation costs. However, it should be kept in mind that during the storage of meat, which has been frozen using this method, dehydration of the outer layer of muscle tissue is up to $5 \mathrm{~mm}$ and product's weight loss rises up to $8 \%$ and, therefore, meat loses its commercial state (Kaale et al., 2011).

3. Processing with ionizing radiation. Radiation processing of food is a process in which food products (packaged or unpackaged) are exposed with carefully controlled ionizing radiation during a fixed period of time to improve their safety and quality.

Radionuclides, which are approved to irradiate food products, include ${ }^{137} \mathrm{Cs}$ and ${ }^{60} \mathrm{Co}$. Radioactive cobalt $\left({ }^{60} \mathrm{Co}\right)$ decomposes into non-radioactive nickel by separating of high-energy particles and X-rays. X-ray radiography destroys fast-growing cells (microbes), but the product still stays radioactive.

Due to its ability to penetrate deeply into the tissue, it can be used to irradiate packaged products (Brewer, 2009).

This type of processing is aimed to be used only for products, which are produced with GMP principles.

Irradiation of food products is used for various purposes (Stefanova, Vasilev and Spassov, 2010):

1) to eradicate from pathogenic microorganisms and parasites;

2) to reduce the level of bacterial contamination which cause product's damage;

3) to prolong storage periods;

4) to make phytosanitary treatment.

Wherever it is possible, food irradiation procedure should be included as a part of the Food Safety Management System ISO 22000.

The highest allowable dose of food irradiation is different in various countries of the world. It is $30 \mathrm{kGy}$ in the United States, in Belgium and Netherlands - $10 \mathrm{kGy}$, and in France - 11 kGy (Ehlermann, 2016). However, in 1981 the United Expert Committee of FAO, IAEA and WHO concluded that irradiation of any food stuff with doses, which do not exceed $10 \mathrm{kGy}$, does not cause the toxic effects in processed products. The use of higher doses (10-50 kGy) of ionizing radiation should be approved by the decision of the United Committee FAO/IAEA/WHO only to process certain types of food products based on their impact on nutritional value, microbiological and toxicological status. (Donskova and Zueva, 2016). In 2011, European Food Safety Authority Commission (EFSA) confirmed the effectiveness of radiation processing to make sure that the microbiological safety of food products and the perspectives of using of ionizing radiation in agricultural biotechnology (Sanzharova, 2016).

More than 220 specialized research centers have been created to keep recording of irradiated agricultural and food products. Each year, the number of irradiated products in the world is estimated at 700-800 thousand tons. The market of irradiation services is about 2 billion dollars and it has a steady upward trend. It is expected that it will reach up to 4.8 billion dollars by 2020 , and to 10.9 billion dollars by 2030. (Belyaev, 2017a, 2017b).

For today, irradiation of food products with ionizing radiation is allowed in 69 countries.

However, processing with ionizing radiation may cause the appearance of extraneous (unwanted) taste and/or odor, as well as bleaching of meat products. Moreover, it also increases the rate of lipid and vitamin oxidation (Timakova et al., 2018).

4. Processing meat under pressure is a new method of preservation with great perspectives for the meat processing industry, despite the still high cost of this technology.

The established pressure level is $300 \mathrm{MPa}$. Under the lower pressure, cells are not destroyed, and the increase of pressure negatively affects the vital activity of microorganisms (Cheftel and Culioli, 1997). Inactivation of the microbial culture of Escherichia coli occurs under the pressure from 500 to $700 \mathrm{MPa}$. At the same time, the studies have shown that non thermic processing of Escherichia coli with $700 \mathrm{MPa}$ pressure with exposure of 30-60 s allows to obtain a completely ready-to-use product with an output readiness of about $100 \%$. At the same time, the product processed with pressure has high organoleptic parameters (Vinnikova and Prokopenko, 2015). It is possible to reduce the action of pressure with additional increasing of temperature: during processing with the pressure of $60 \mathrm{MPa}$ and increasing of temperature from 25 to $93.6^{\circ} \mathrm{C}$, there is a significant decrease in microbial contamination. Pressure of $200 \mathrm{MPa}$ and low temperatures (less than $0{ }^{\circ} \mathrm{C}$ ) prolong the shelf life of the foodstuffs without freezing of liquid part (Okamoto and Suzuki, 2002).

The inhibiting effect on microorganisms while processing with high pressure is achieved with the damage of cell membrane, the conformation of protein molecules, cellular proteins and enzymes due to the breakage of hydrophobic bond and with increasing of pressure it the breakdown of hydrogen bonds occurs. 
In addition, high pressure is one of the promising methods of processing food raw materials; it almost excludes the loss of nutrient components and extractives that are observed in any traditional heat processing. High bacteriological and bacteriostatic pressure affects the vital functions of microorganisms (Shelikhov, Gladkaya and Sasina, 2010).

Thus, foodstuffs, which are processed with high pressure, have unique composition and properties. Specificity of ready-to-use products' properties is associated with changes in some special structural elements contained in the raw material. For today, the effect of non-thermal processing of meat is insufficiently studied; therefore, it poses a significant interest for scientists worldwide. The entire group of researches is needed to be involved for the establishing of rational pressure regimes for this raw material, as well as to study the quality characteristic of ready-to-use products obtained using the high pressure technology.

5. Processing of meat and meat products by laser radiation. Biological action of laser radiation causes numerous structural, functional and biochemical changes occurring in a living body and animal raw material.

Partial absorption of energy that falls on the tissue and reflection of its residual part occurs when laser radiation interacts with biological tissues. At the same time, the biological effect of laser radiation on living organism is determined by the structural and physiological properties of its particular tissues and characteristics of laser radiation (Vyayzenen et al., 2010).

The optimal irradiation dose for the effective inhibition of pathogenic microorganisms in the meat raw material is $1.5-2 \mathrm{Mrad}$. In order to inactivate Clostridium botulinum the dose of radiation should be increased up to 3-5 Mrad (Murashov and Zhuravleva, 2014).

Laser processing has following advantages in comparison with traditional methods:

1) completely automatic process, where the lack of contact with the irradiated object is the most important feature;

2) stability in work,

3) special storage conditions of the product after treatment are excluded.

However, it is necessary to provide technological lines of industrial manipulators for accurately control the laser radiation impact on the human body.

6. Processing of meat by ultraviolet irradiation. According to our previous studies of the use of UV radiation on the meat surface, it has been noted that the highest bactericidal efficiency has UV radiation with a wavelength of $253.7 \mathrm{~nm}$. Similarly, it was observed that the effectiveness of UV radiation depends on the radiation exposure and intensity of radiation on mold spores. UV rays in small doses stimulate the growth of fungi colonies. However, large doses of UV rays reduce the germination and growth of sowed spores, and much stronger doses have damaging impact on all mold spore cells.

It should be kept in mind that some types of bacteria form spores, which germinate in the presence of favorable conditions. Moreover, spores are much more resistant to UV rays than bacteria: an average dose for elimination of spores is 10 times greater, than for destruction of vegetative forms (Sokolenko et al., 2015).

However, ultraviolet radiation has numerous disadvantages (Degala et al., 2018), such as:

1) UV rays affect only microorganisms on the surface of the product;

2) The efficiency against large colonies of microorganisms is insufficient since significant part of cells continues to develop, especially after cessation of irradiation;

3) vitamins are destructed (for example, pyridoxine) when UV irradiation is applied;

4) meat surface becomes darker as a result of myoglobin destruction as well as transition of $\mathrm{MbO}_{2}$ into metmyoglobin;

5) oxidative processes in fats intensify significantly as a result of ozone formation;

6) it is very difficult to achieve equal irradiation of carcasses, because of the inevitable presence of shaded areas on meat carcasses.

7. Ozonation of meat. Ozone is a very strong natural disinfectant. The application of ozone technologies is based on characteristics of gaseous ozone at certain concentrations and exposures to destroy microorganisms, bacteria, spores and viruses (Rodionova, 2017).

Regarding the mechanism of ozone's action on a microbial cell, it is known, that under the influence of the destruction of plasmatic membrane's phospholipids, cell and associated fragmented proteins, the integrity of its germs is disturbed and they are deformed, separated and exposed to lysis. The products of ozone lysis, which were formed at the same time, become an instrument of additional damage of intracellular structures that provide metabolic processes. The cytolysis is completed by the release of the stock of lithium enzymes (Belykh et al., 2010).

Studying the impact of ozone on the surface microflora of chilled meat, we have found that the resistance of bacterium to ozone action varies both against the type of bacteria and the concentration of ozone as well as environmental conditions (Rodionova, 2017).

Ozone technology in meat production has following advantages (Rezgo, 2011):

1) high efficiency of disinfection (ozone has a higher oxidation potential than chlorine and its derivatives);

2) the possibility to obtain ozone directly from the air in a place of oxygen consumption;

3 ) environmental safety and the absence of harmful side-effects due to the rapid decomposition of ozone to oxygen; 
4) environmental compatibility (from all known oxidants only oxygen and limited number of peroxide compounds exist in nature and participate in biological processes);

5) the application of ozone can significantly increase the shelf life of products without losing their freshness and high nutritional qualities;

6) high economic efficiency in comparison to other disinfectants (ozone is 2 times cheaper than with the use of other disinfectants).

The disadvantage of the use of ozone is that it is a strong oxidant of fats and blood pigments. Due to this adipose tissue turns faster and muscle tissue darkens (Brewer, 2009).

In our opinion, ozone should be used to disinfect empty chamber before loading the product or to apply it at low concentrations during meat processing.

\section{Chemical methods:}

1. Chemical preservatives. Various microorganisms produce organic acids and alcohols by anaerobic fermentation of food substrates. These substances can act in food's preservation by inhibiting of other organisms that are concomitantly present and which may spoil food or make it toxic. For example, is a frequently effective inhibitory agent used in fresh meat preservation; however, other organic acids have also been found to be responsible for discoloration and production of pungent odors (Zhou, $\mathrm{Xu}$ and Liu, 2010).

Salts, such as sodium lactate have been used in the meat industry because of their ability to increase flavor, prolong shelf life, and improve the microbiological safety of products (Diez et al., 2009).

The antimicrobial effects of lactates are due to their ability to lower water activity and the direct inhibitory effect of the lactate ion (Houtsma, Wit and Rombouts, 1993; Koos and Jansener, 1995).

Several researchers have successfully extended the shelf life of fresh meat products (Vasavada et al., 2003) by adding sodium lactate. Nadeem et al. (2003) extended shelf life of freshly slaughtered sheep and goat carcasses stored at $5-7^{\circ} \mathrm{C}$ for 3 and 2 days respectively, after spraying the carcasses with solution ' $\mathrm{B}$ ' containing potassium sorbate, sodium acetate, sodium citrate, sodium lactate each at $2.5 \%$ and sodium chloride at $5 \%$, when compared with solution 'A' (without potassium sorbate) and control.

2. Biopreservation and natural antimicrobials. Recently, the chemical food preservatives that were conventionally used in food industry to prevent the spoilage caused by pathogenic microorganisms, were analyzed due to their adverse effects and environmental concerns. Biological preservation is the use of naturally derived antimicrobial agents endowed with high antimicrobial potential to preserve food and beverages and thus extend their shelf lives (Yusuf, 2018).
Natural antimicrobial agents for foodstuffs which are processed under minimal thermal conditions (including meat and poultry meat products) are very attractive alternative against chemical preserve agents. The use of natural antimicrobial agents together with innovative packaging food technologies is ideal for elimination of food spoilage (Pisoschi et al., 2018). Natural antimicrobial agents include organic acids and their salts, nisin and other bacteriocins, various active components of microbiological or animal origin, vegetable essential oils, phenolic compounds and components of smoke (Yusuf, 2018). Organic acids and their salts are effective in soluble form for spraying or their immersion into the meat package processed for realization. Besides, they are effective in the form of additives to minced meat. Salts of organic acids are also characterized by antibacterial effects on raw cattle and poultry meat, but differ from acids that reduce the $\mathrm{pH}$ of muscle tissue only within limited measures. This is also true for salts of weak lipophilic acids - benzoin and sorbic (Sokolenko et al., 2015).

Potassium sorbate is well known as a substance that suppresses bacterial growth causing beef damage.

An increase interest in the use of bacteriogenic lactic acid bacteria (LAB) as protective cultures for the biological conservation of meat and meat products, has been observed in two last decades. Numerous forms and strains of LAB are capable to produce a significant amount of bacteriocin which suppresses pathogenic microorganisms in fresh meat. Regarding the control of spoilage microorganism reproduction and prolongation of shelf life, the use of bacteriogenic LAB for fresh meat and poultry has its limitations (Zhou, Xu and Liu, 2010).

The direct additive agents with bacteriosinogenic properties such as nizin, enterocyn and lacticin into row meat and meat is an alternative of protective cultures of microorganisms. It is known that these drugs are effective against a wide range of pathogenic bacteria and damage microorganisms, but their use is often limited by low volumes of their production, high prices, and thus low availability to be used at meat processing enterprises (Pisoschi et al., 2018).

The vital activity of damage microorganisms in meat raw materials and meat can be controlled with the help of antimicrobial agents of microbiological or animal origin, which are differ from bacteriocin, produced by LAB.

Rutterin and diacetyl are attributed to powerful antimicrobial agents, which are used to control harmful microorganisms of meat raw materials. The last one can be used to inhibit the growth of spoilage microorganisms only together with carbon dioxide, which allows to maintain red meat color and to prevent its darkening (McMillin, 2017).

Antimicrobial agents of plant origin include spices and herbs, essential oils, natural phenolic compounds of plants and smoke. They have antimicrobial and antioxidant properties and can be used to prolong the shelf life and 
increase the safety of rapidly spoiled foods, including meat raw materials. It should be emphasized that the use of essential oils and other extracts of spices and herbs as natural fresh preservatives of row meat has its limitations. First of all, effective antimicrobial dosages might exceed the level of organoleptic perception due to the possible changes in taste (Yusuf, 2018; Pisoschi et al., 2018).

Except of the physical and chemical methods of preserving meat, the packaging of meat and meat raw materials in modified atmosphere, the system of 'active packaging' and the system of aseptic packaging are becoming increasingly popular and widespread.

1. Systems connected with using of 'active packaging'. The purpose of the 'active packaging' is the direct effect on the product to insure its higher quality, as well as to extend the period of stability and suitability for consumption (McMillin, 2017).

Packing technologies with using of 'active packaging' may include (Zhou, $\mathrm{Xu}$ and Liu, 2010):

- addition of chemicals into the packaging or in packaging materials that adsorb and remove oxygen from the atmosphere inside the package;

- the use of preservatives, bactericidal substances and antioxidants that are released from the packaging material;

- the use of humidity regulators;

- the use of technology, which allows to control the smell and taste;

- the use of light absorbers;

- the use of package that emits mineral substances retaining product's color;

- improvement of package surface to change its permeability.

The product is sterilized separately during aseptic packaging, in contrast with the traditional system, where the packed product is sterilized.

Systems with aseptic packaging are characterized with following useful advantages:

a) shorter term effect of high temperature allows to retain nutritional properties, taste;

b) packages are made under the sterile conditions of packaging machine with excess pressure and sterile air;

c) sterilization of product occurs as a result of the its thermal stabilization over a short period of time, through the high temperature and cooling;

d) long shelf life of products without freezing;

e) additional protection of products by addition of inert gas into the package;

f) high decontamination level of packaging material or package.

Other different ways of preserving food quality are also used, apart from package. (Tyaglova and Makarova, 2018).

2. Vacuum packaging. Vacuum packaging materials for primal cuts are usually three layered co-extrusions of ethyl vinyl acetate / polyvinylidene chloride / ethyl vinyl acetate, which generally have an $\mathrm{O}_{2}$ permeability of less than $15.5 \mathrm{ml} \mathrm{m}^{-2}(24 \mathrm{~h})^{-1}$ at 1 atmosphere under the polyvinylidene chloride layer (Lonergan, Topel and Marple, 2019). The lack of $\mathrm{O}_{2}$ in packages may minimize the oxidative deteriorative reactions and reduce growth of aerobic bacteria. Vacuum skin packaging (VSP) systems for placing of retail cut in a barrier styrene or polypropylene tray and vacuum sealing barrier films compressed under the heat for conforming to the product form are usually used for low $\mathrm{O}_{2}$ packaging of retail meat cuts (VSP) (Belcher, 2006). VSP packaging equipment removes atmospheric air or flushes the air from the package with gaseous compounds such as $\mathrm{N}_{2}, \mathrm{CO}_{2}$ or mixtures of $\mathrm{N}_{2}$ and $\mathrm{CO}_{2}$ before heat sealing the film layers. Nylon barrier polymer of polyvinylidene chloride or ethylene vinyl alcohol are common construction for the top and bottom package webs, tie layer and ionomer. Nylon provides bulk, toughness and low melting point, while the barrier layer prevents vapor permeation and the ionomer gives necessary sealing characteristics (Pisoschi et al., 2018). A variation of VSP is for the lidding film to have outer barrier and inner air-permeable layers so that before retail display, the outer barrier film layer is peeled away from the permeable layer so that air can then contact the meat product and result in a bloomed color (Wang et al., 2019; Kameník et al., 2014; Li et al., 2012).

3. Modified Atmosphere Packaging (MAP). The peculiarities of MAP are to replace the air in the package with a mixture of gases (oxygen, carbon dioxide and nitrogen). The ratio of gases, especially $\mathrm{O}_{2}$, depends on the type of packaged product. Low levels of oxygen prevent the growth of fungi, bacteria and other microorganisms. MAP is a natural and environmentally friendly product preservation technology. The use a modified gas space allows you to maintain the quality, taste and appearance of the product, increase the shelf life (Rodionova and Paliy, 2018).

MAP technology allows to:

— increase significantly product's shelf life;

- reduce or completely exclude the use of preservatives;

- expand the geography of sales;

- reduce moisture exchange with the environment;

- produce a fundamentally new product with preservation of its original color;

- pack up products in attractive package without damage (crush) of the packaged product.

However, when meat and meat products are packaged in modified atmosphere, the following factors have to be taken into account:

- packaging material, its composition and barrier properties;

- choice of gas and the percentage of gases in the mixture;

- preparation of the product for packaging;

- the correct ratio product/gas; 
- control of the packaging quality and storage of the packaged product.

Product which is intended for packaging, should have temperature inside the thickness of the product not lower than $0{ }^{\circ} \mathrm{C}$ and not higher than $4^{\circ} \mathrm{C}$. Depending on the product, The time from the end of the manufacturing process to the beginning of the packaging process in the conditions and storage regimes, established by the normative documents, should not exceed from 2 to 72 hours (Wang et al., 2019).

It should be noted that now this technology of food packaging is the most promising and widely used all over the world since it prolongs the shelf life of the finished product in 3-5 times, and the success of the marketing and realization of products depends mostly on it (McMillin, 2017).

Conclusions. Continuous scientific and technological progress in recent years has contributed to the development and implementation of new, modern technologies that help to increase the shelf life of meat raw materials. Today, the use of physical and chemical methods of preserving meat and meat products, modern packaging systems, reduces production risks, prolongs shelf life, and protects against secondary contamination, but each of them has its own disadvantages, which in one or another way affect the way on product quality indicators during storage. Therefore, the search of modern and ecological methods of preservation, with the aim to prolong the period of their realization and transportation, in condition to maintain the quality and safety indicators, remains a topical issue of food industry.

Prospects for further research. To develop complex contemporary and ecological methods of meat and meat products' processing using 'active packaging' system and physical methods of preservation (such as laser and ionizing radiation) as well as to develop a method of meat preserving using aseptic packaging and nanotechnology systems.

\section{References}

Belcher, J. N. (2006) 'Industrial packaging developments for the global meat market', Meat Science, 74(1), pp. 143-148. doi: 10.1016/j.meatsci.2006.04.031.

Belyaev, N. M. (2017a) 'Scientific and practical studies in the field of influence of ionizing irradiation on quality and preservation of foodstuffs (on the example of products from poultry meat)', 21 Century: Fundamental Science and Technology: proceedings of the conference, North Charleston, USA, 24-25 April 2017, 12(2), pp. 82-85. Available at: https://www.elibrary.ru/item.asp?id=29244232.

Belyaev, N. M. (2017b) 'Theoretical questions of processing of poultry meat by ionizing radiation' [Teoreticheskie voprosy obrabotki myasa ptitsy ioniziruyushchim izlucheniem], Scholarly Discussion: Innovations of the Modern World: Proceedings of LXI International Scientific-Practical Conference, Moscow, January 2017 [Nauchnaya diskussiya: innovatsii $v$ sovremennom mire: materialy LXI Mezhdunarodnoy nauchnoprakticheskoy konferentsii, Moskva, yanvar' 2017 g.], 1, pp. 2932. Available at: https://www.elibrary.ru/item.asp?id=27715699. [in Russian].

Belykh, I. A., Vysekantsev, I. P., Grek, A. M., Sakun, O. V. and Maruschenko, V. V. (2010) 'The toxic action of ozone on bacterium Staphylococcus aureus, funguses Candida albicans and spore shape Bacillus subtilis' [Toksicheskoe deystvie ozona na mikroorganizmy Staphylococcus aureus, drozhzhepodobnye griby Candida albicans i sporovye formy Bacillus subtilis], Modern Problems of Toxycology [Sovremennye problemy toksikologii], 2-3, pp. 45-49. Available at: http://protox.medved. kiev.ua/index.php/en/issues/2010/2-3/item/366. [in Russian].

Brewer, M. S. (2009) 'Irradiation effects on meat flavor: A review', Meat Science, 81(1), pp. 1-14. doi: 10.1016/j.meatsci. 2008.07.011.

Cheftel, J. C. and Culioli, J. (1997) 'Effects of high pressure on meat: A review', Meat Science, 46(3), pp. 211-236. doi: 10.1016/S0309-1740(97)00017-X.

Degala, H. L., $\quad$ Mahapatra, A. K., Demirci, A. and Kannan, G. (2018) 'Evaluation of non-thermal hurdle technology for ultraviolet-light to inactivate Escherichia coli K12 on goat meat surfaces', Food Control, 90, pp. 113-120. doi: 10.1016/j.foodcont.2018.02.042.

Diez, A. M., Santos, E. M., Jaime, I. and Rovira, J. (2009) 'Effectiveness of combined preservation methods to extend the shelf life of Morcilla de Burgos', Meat Science, 81(1), pp. 171-177. doi: 10.1016/j.meatsci.2008.07.015.

Donskova, L. A. and Zueva, O. N. (2016) 'Protein components as indicator functionality and quality of meat product: characteristic and evaluation methodology' [Belkovyy komponent kak pokazatel' funktsional'nogo naznacheniya i kachestva myasnykh produktov: kharakteristika i metodologiya otsenki], Technology and Merchandising of the Innovative Foodstuff [Tekhnologiya $i$ tovarovedenie innovatsionnykh pishchevykh produktov], 3, pp. 73-79. Available at: https://www. elibrary.ru/item.asp?id=26337362. [in Russian].

Ehlermann, D. A. E. (2016) 'Particular applications of food irradiation: Meat, fish and others', Radiation Physics and Chemistry, 129, pp. 53-57. doi: 10.1016/j.radphyschem.2016.07. 027.

Houtsma, P. C., de Wit, J. C. and Rombouts, F. M. (1993) 'Minimum inhibitory concentration (MIC) of sodium lactate for pathogens and spoilage organisms occurring in meat products', International Journal of Food Microbiology, 20(4), pp. 247-257. doi: 10.1016/0168-1605(93)90169-H.

Kaale, L. D., Eikevik, T. M., Rustad, T. and Kolsaker, K. (2011) 'Superchilling of food: A review', Journal of Food Engineering, 107(2), pp. 141-146. doi: 10.1016/j.jfoodeng.2011. 06.004.

Kameník, J., $\quad$ Saláková, A., $\quad$ Pavlík, Z., Bořilová, G., Hulanková, R. and Steinhauserová, I. (2014) 'Vacuum skin packaging and its effect on selected properties of beef and pork meat', European Food Research and Technology, 239(3), pp. 395402. doi: 10.1007/s00217-014-2233-9.

Koos, J. de and Jansener, K.-E. (1995) 'Lactate: An opportunity to improve safety of processed meat and poultry' [Laktat: Chance zur Verbesserung der Produktsicherheit bei Fleischwaren], Fleischwirtschaft (Frankfurt), 75(11), pp. 12961298. [in German]. 
Li, X., Lindahl, G., Zamaratskaia, G. and Lundström, K. (2012) 'Influence of vacuum skin packaging on color stability of beef longissimus lumborum compared with vacuum and highoxygen modified atmosphere packaging, Meat Science, 92(4), pp. 604-609. doi: 10.1016/j.meatsci.2012.06.006.

Lonergan, S. M., Topel, D. G. and Marple, D. N. (2019) 'Chapter 15 - Packaging for meat and meat products', in The Science of Animal Growth and Meat Technology. $2^{\text {nd }}$ ed. Elsevier, pp. 255-269. doi: 10.1016/B978-0-12-815277-5.00015-9.

McMillin, K. W. (2017) 'Advancements in meat packaging', Meat Science, 132, pp. 153-162. doi: 10.1016/j.meatsci.2017.04. 015.

Mok, J. H., Her, J.-Y., Kang, T., Hoptowit, R. and Jun, S. (2017) 'Effects of pulsed electric field (PEF) and oscillating magnetic field (OMF) combination technology on the extension of supercooling for chicken breasts', Journal of Food Engineering, 196, pp. 27-35. doi: 10.1016/j.jfoodeng.2016.10.002.

Murashov, I. D. and Zhuravleva, D. A. (2014) 'Processing of meat and meat products by laser irradiation as an alternative to increase shelf life' [Obrabotka myasa i myasnykh produktov lazernym oblucheniem kak al'ternativnyy sposob uvelicheniya sroka khraneniya], Technical Sciences - Technology of Food Products [Tekhnicheskie nauki - tekhnologii prodovol'stvennykh tovarov], 12, pp. 8-10. Available at: https://www.sworld.com.ua/ index.php/ru/technical-sciences-314/technology-of-food-prod ucts-314/23149-314-359. [in Russian].

Nadeem, A. S., Chattopadhyay, U. K., Sherikar, A. T., Waskar, V. S., Paturkar, A. M., Latha, C., Munde, K. D. and Pathare, N. S. (2003) 'Chemical sprays as a method for improvement in microbiological quality and shelf-life of fresh sheep and goat meats during refrigeration storage $\left(5-7^{\circ} \mathrm{C}\right)$,' Meat Science, 63(3), pp. 339-344. doi: 10.1016/S0309-1740(02) 00091-8.

Nastasijevic, I., Lakicevic, B. and Petrovic, Z. (2018) 'Cold chain management in meat supply: 'Old' and novel strategies' [Upravlenie kholodil'noy tsep'yu pri postavkakh myasa: 'starye' i novye strategii], Theory and practice of meat processing [Teoriya i praktika pererabotki myasa], 2(4), pp. 20-34. doi: 10.21323/ 2414-438X-2017-2-4-20-34. [in Russian].

Okamoto, A. and Suzuki, A. (2002) 'Effects of high hydrostatic pressure-thawing on pork meat', in Hayashi, R. (ed.) Trends in High Pressure Bioscience and Biotechnology: Proceedings First International Conference on High Pressure Bioscience and Biotechnology (Kyoto, Japan, 26-30 November 2000). Elsevier (Progress in Biotechnology, 19), pp. 571-576. doi: 10.1016/S0921-0423(02)80155-1.

Pisoschi, A. M., Pop, A., Georgescu, C., Turcuş, V., Olah, N. K. and Mathe, E. (2018) 'An overview of natural antimicrobials role in food', European Journal of Medicinal Chemistry, 143, pp. 922-935. doi: 10.1016/j.ejmech.2017.11.095.

Rezgo, G. Ya. (2011) 'Ozonation as an innovation method of storage of semi-smoked sausages' [Ozonirovanie kak innovatsionnyy metod khraneniya polukopchenykh kolbas], Foodstuffs Commodity Expert [Tovaroved prodovol'stvennykh tovarov], 2, pp. 35-39. Available at: https://www.elibrary.ru/item. asp?id=21086627. [in Russian].

Rodionova, K. O. (2017) 'The effectiveness of the use of ozone for disinfection of objects of veterinary supervision in the meat processing plants' [Efektyvnist zastosuvannia ozonu pry znezarazhenni obiektiv veterynarnoho nahliadu na miasopererobnykh pidpryiemstvakh], Bulletin of the Sumy
National Agrarian University. Series 'Veterinary Medicine' [Visnyk Sumskoho natsionalnoho ahrarnoho universytetu. Seriia 'Veterynarna medytsyna'], 1, pp. 74-78. Available at: http://nbuv. gov.ua/UJRN/Vsna_vet_2017_1_16. [in Ukrainian].

Rodionova, K. O. and Paliy, A. P. (2018) 'Influence of modern vacuum packaging on quality and safety of sausage products', Journal for Veterinary Medicine, Biotechnology and Biosafety, 4(1), pp.18-23. Available at: http://nbuv.gov.ua/ UJRN/jvmbb_2018_4_1_6.

Sanzharova, N. I. (2016) Prospects for the Use of Radiation Technologies in Agro-Industrial Complex of the Russian Federation [Perspektivy primeneniya radiatsionnykh tekhnologiy $v$ agropromyshlennom komplekse Rossiyskoy Federatsii]. Available at: http://nsrus.ru/files/obninsk60/typhoon/Sanzharova.pdf. [in Russian].

Shelikhov, P. V., Gladkaya, A. D. and Sasina, I. A. (2010). 'Study of application of high pressure as ecologically safe method of treatment of food products' [Izuchenie primeneniya vysokogo davleniya kak ekologicheski bezopasnogo sposoba obrabotki pishchevykh produktov], Collection of Scientific Works of Vinnytsia National Agrarian University. Series: Agricultural Sciences [Zbirnyk naukovykh prats Vinnytskoho natsionalnoho ahrarnoho universytetu. Seriia: Silskohospodarski nauky], 5, pp. 217-221. Available at: http://agrojournal.vsau.org/files/pdfa/ 1225.pdf. [in Russian].

Sokolenko, A. I., $\quad$ Piddubnyi, V. A., Hidzhelitskyi, V. M., Shevchenko, O. Yu. and Vasylkivskyi, K. V. (2015) PhysicoChemical Methods of Processing of Raw Materials and Foodstuffs [Fizyko-khimichni metody obrobky syrovyny i kharchovykh produktiv]. Kyiv: Kondor. ISBN 9786177278053. [in Ukrainian].

Stefanova, R., Vasilev, N. V. and Spassov, S. L. (2010) 'Irradiation of food, current legislation framework, and detection of irradiated foods', Food Analytical Methods, 3(3), pp. 225-252. doi: 10.1007/s12161-009-9118-8.

Stonehouse, G. G. and Evans, J. A. (2015) 'The use of supercooling for fresh foods: A review', Journal of Food Engineering, 148, pp. 74-79. doi: 10.1016/j.jfoodeng.2014.08. 007.

Timakova, R. T., Tikhonov, S. L., Tikhonova, N. V. and Gorlov, I. F. (2018) 'Effect of various doses of ionizing radiation on the safety of meat semi-finished products', Foods and Raw materials, 6(1), pp. 120-127. doi: 10.21603/2308-4057-2018-1120-127.

Tyaglova, A. M. and Makarova, N. V. (2018) 'Development of technology for the production of culinary dishes from meat using an antibacterial edible food film' [Razrabotka tekhnologii proizvodstva kulinarnykh blyud iz myasa s ispol'zovaniem antibakterial'noy s"edobnoy pishchevoy plenki], Nutritional Innovations in Biotechnology: abstracts of the VI international scientific conference of students, PhD students and young scientists, Kemerovo, 16 May 2018 [Pishchevye innovatsii $v$ biotekhnologii: sbornik tezisov VI mezhdunarodnoy nauchnoy konferentsii studentov, aspirantov $i$ molodykh uchenykh, Kemerovo, 16 maya 2018 g.], 2, pp. 133-135. Available at: https://www.elibrary.ru/item.asp?id=35043722. [in Russian].

Vasavada, M., Carpenter, C. E., Cornforth, D. P. and Ghorpade, V. (2003) 'Sodium levulinate and sodium lactate effects on microbial growth and stability of fresh pork and turkey sausages', Journal of Muscle Foods, 14(2), pp. 119-129. doi: 10.1111/j.1745-4573.2003.tb00694.x. 
Vinnikova, L. G. and Procopenko, I. A. (2015) 'The application of high pressure as an alternative to thermal processing of poultry meat', Eastern-European Journal of Enterprise Technologies, 3(10), p. 31-36. doi: 10.15587/17294061.2015.44241.

Vyayzenen, G. N., Vyayzenen, G. A., Danilovskikh, M. G., Vyayzenen, A. G., $\quad$ Raudik, O. A., $\quad$ Sulyarova, N. V., Migorodskiy, G. G., Gerasimova, N. V., $\quad$ Yerykova, Ye. M., Shkurko, D. I., Razaev S. V. and Nekrutov, A. V. (2010). 'Influence of laser technology on meat productivity of chicken broilers' [Vliyanie lazernoy tekhnologii na myasnuyu produktivnost' tsyplyat-broylerov], Meat Industry [Myasnaya industriya], 2, pp. 17-19. Available at: https://www.elibrary.ru/ item.asp?id=15111049. [in Russian].

Wang, C., Wang, H., Li, X. and Zhang, C. (2019) 'Effects of oxygen concentration in modified atmosphere packaging on water holding capacity of pork steaks', Meat Science, 148, pp. 189-197. doi: 10.1016/j.meatsci.2018.10.001.

Wu, C., Yuan, C., Ye, X., Hu, Y., Chen, S. and Liu, D. (2014) 'A critical review on superchilling preservation technology in aquatic product', Journal of Integrative Agriculture, 13(12), pp. 2788-2806. doi: 10.1016/S2095-3119(14)60841-8.

Yusuf, M. (2018) 'Chapter 12 - Natural antimicrobial agents for food biopreservation', in Grumezescu, A. M. and Holban, A. M. (eds.) Food Packaging and Preservation. Elsevier (Handbook of Food Bioengineering, 9), pp. 409-438. doi: 10.1016/B978-0-12-811516-9.00012-9.

Zhou, G. H., Xu, X. L. and Liu, Y. (2010) 'Preservation technologies for fresh meat - A review', Meat Science, 86(1), pp. 119-128. doi: 10.1016/j.meatsci.2010.04.033. 